\title{
PROXIMATE COMPOSITIONS, PHYSICOCHEMICAL AND ORGANOLEPTIC PROPERTIES OF DRINKS PRODUCED FROM BEETROOT AND ROSELLE
}

\author{
Ebiringa, D. C. ${ }^{1}$ and Onyeneke, E. N. ${ }^{2}$ \\ ${ }^{1}$ Department of Food Science \& Technology, Imo State University, Owerri \\ ${ }^{2}$ Department of Nutrition and Dietetics, Imo State University, Owerri
}

Corresponding author's email: danchidozie@yahoo.com

\begin{abstract}
Production and quality evaluation of drinks from beetroot and roselle were carried out. Single juice extraction was prepared from beetroot and roselle (hibiscus) respectively. Mixed drink samples were formulated by mixing beetroot and roselle juice extracts in the ratios of 1:0 (sample A), 3:1 (sample B), 1:1 (sample C), 1:3 (sample D) and 0:1 (sample E-zobo drink). The drinks were evaluated for proximate compositions, vitamin A, Vitamin C, mineral contents, pH, Titratable acidity, total solids and sensory properties. Moisture content ranged from $88.13 \%$ for sample E to $93.03 \%$ for sample A. The values were not significantly different ( $p>0.05$ ). Ash content ranged from $0.45 \%$ for sample $E$ to 0.67 for sample $A$ and the values were significantly different ( $p<0.05)$. Fat content ranged from $0.13 \%$ for sample $E$ to $0.25 \%$ for sample $A$ and the values were not significantly different. $(P>0.05)$. Carbohydrate content ranged from $5.75 \%$ for sample A to $11.20 \%$ for sample E and the values were not significantly different. Vitamin A content ranged from 24.64 to $38.04 \mathrm{mg} / 100 \mathrm{~g}$; Vitamin C ranged from 5.67 to $17.08 \mathrm{mg} / \mathrm{l00g}$; phosphorous ranged from 38.49 to $86.97 \mathrm{mg} / 100 \mathrm{~g}$; iron: 4.79 - 9.69; magnesium: 3.01 - 7.71; potassium: 4.01 - 7.40; calcium increased from 3.50 to $6.29 \mathrm{mg} / 100 \mathrm{~g}$. The titratable acidity and total solids showed increases in values while $\mathrm{pH}$ showed a decrease from sample A down to E. The sensory scores indicated that there were significant differences in all the attributes (appearance, aroma, taste, mouthfeel and overall acceptability) of the drinks. However sample E(zobo drink only) was mostly preferred.
\end{abstract}

Keywords: Proximate, physico-chemical, organoleptic, beetroot, roselle, drinks https://dx.doi.org/10.4314/jafs.v17i1.3

\section{INTRODUCTION}

Every drink has its distinct properties and characteristics such as organoleptic properties as well as nutritional, physical and chemical benefits which play an important role in the body such as regulation, maintenance of blood pressure and adequate digestion of food. Beetroot is the taproot portion of the beet plant (Beta vulgaris) known as garden, table or red beets. The taproot and the leaves of garden beet or golden beet are well consumed in developing countries. Eastern Europeans use it as chops and also incorporate it into soups while the Indians prefer it cooked and spiced (Porto et al., 2017). Beetroot can be fermented into wine but in recent trends, it is processed into readily digestible juice and drink using different drying techniques to compare its sensory and proximate properties as well as flavoring agent to enhance the colour of the drink (Ansaic et al., 2017). 
Beet root can be classified based on the plant parts and their uses into two categories; 'leaf beets' and 'tuberous beets'. Leaf stalks and roots are edible. It has been reported that beet root is rich in minerals and vitamins with lots of health benefits (Kanika, 2012). Roselle is a species of the Hibiscus (Hibiscus sabdariffa). Hibiscus is a genus of flowering plants in the malvaceae family. Roselle plants are known for their large, colourful flowers. They can be red, yellow, white or peach coloured. The red flowers of this variety are most commonly cultivated for drinks and medical purposes and dietary supplements. Hibiscus drink can be used for the treatment of constipation, liver disease and cold symptoms (Chen et al., 2005). Zoborodo, popularly known as zobo drink, is a drink made from Roselle; it is extracted from the dried petals.

The drinks made separately from beetroot and Roselle have varied benefits. However, some consumers have some reservation on the taste of zobo drink from Roselle. The aim of this study is to derive drinks from blends of beetroot and Zobo which will satisfy consumers organoleptically as well as meet with nutritional requirements.

\section{MATERIALS AND METHODS}

The petals of roselle (Hibiscus sabdariffa), the beetroot and all other materials were purchased from Mile 1 market, Diobu Port-Harcourt, Rivers state, Nigeria. The petals of roselle and the beetroot were sorted and washed with clean water for the production of the drinks.

\section{Production of Drink from Beetroot}

Figure 1 shows the process used in producing drink from Beetroot. The beet roots were sorted to remove bad and rotten ones. They were then washed to remove sand and mould. The beetroots were peeled with knife, re-washed and sliced into $2-3 \mathrm{~mm}$ thickness. Two kilogrammes $(2 \mathrm{~kg})$ of the sliced beetroots were blended with one litre of water. The mixture was filtered with muslin cloth folded into 2, 4 and 8 layers, respectively, to obtain fresh beetroot drink. The filtered juice was filled into sterilized bottles and was properly covered. It was pasteurized at $80^{\circ} \mathrm{C}$ for 8 minutes.

\section{Production of Zobo drink from Roselle}

The steps used in producing zobo drink from Roselle are shown in Fig 2.

The sorted hibiscus petals were washed with clean water to remove dirts and impurities.

One and a half kilograms $(1.5 \mathrm{~kg})$ of the cleaned petals were put into a deep pot and 5 litres of water added. They were boiled for $30-45$ minutes. During the process, $3 \mathrm{~g}$ of ginger and $2 \mathrm{~g}$ of garlic were added to the boiling liquid. After boiling, it was set aside to cool to room temperature. After cooling, the juice was poured through a muslin cloth and latter in a chiffon cloth to remove even the finest particles. The juice was then packaged into clean sterilized bottles.

\section{Mixing of Drinks from Roselle and Beet Root in varying proportions}

Drinks from beetroot and Roselle (Zobo) were mixed in varying proportions as shown in Table 1. 
Journal of Agriculture and Food Sciences

Ebiringa, D.C. and Onyeneke, E. N. 40 Volume 17 Number 1, April 2019 pp 38- 53

\section{Proximate Analyses of the Drink Samples}

The moisture, fat, protein, ash, and carbohydrate contents of the drink samples were determined using the AOAC (2012) methods

\section{Determination of Mineral Contents}

\section{Determination of Phosphorus}

Phosphorus was determined by the molybdovenadate colorirnetric method (James, 1995). A measured volume $(2 \mathrm{ml})$ of dry ash digest phosphorus solution were measured into different flasks to serve as reagent blank and standard respectively. Two of phosphorus color reagent (molybdovanadate solution) were added to each flask and allowed to stand at room temperature for 15 minutes. The content of each flask was diluted to the $50 \mathrm{ml}$ mark with distilled water and its absorbance measured in a spectrophotometer at a wavelength of 540nm. The phosphorus was calculated using the equation:

$$
\mathrm{P}(\mathrm{mg} / \mathrm{l100g})=\frac{100}{\text { Wt of sample }}^{\mathrm{x}} \text { As } \quad \underline{\mathrm{Av}} \times \quad \begin{array}{llll}
\mathrm{C} & \mathrm{x} & \underline{\mathrm{V}}_{1} \\
\mathrm{~V}_{\mathrm{A}} & &
\end{array}
$$

Where:

$\mathrm{Wt}=$ weight of sample used, $\mathrm{Av}=$ Absorbance of standard phosphorus solution, As $=$ Absorbance of phosphorus solution, $\mathrm{C}=$ Concentration of standard phosphorus solution, $\mathrm{V}_{1}=$ total extract volume, $\mathrm{V}_{\mathrm{A}}=$ volume of extract analyzed

\section{Determination of Iron Content}

Iron in the sample was determined by atomic absorption spetrophotometer (AAS) using methods described by Kirk and Sawyer (1998). The sample extract were aspirated into the instrument and their respective absorbance determined using the equation:

$\mathrm{Fe}(\mathrm{rng} / 100 \mathrm{~g})=\frac{100}{\mathrm{~W}} \quad \mathrm{x} \quad \frac{\mathrm{XD}}{100}$

Where $\mathrm{W}=$ weight of the sample in grammes $\mathrm{X}=$ concentration in $\mathrm{ppm}, \mathrm{D}=$ dilution factor

\section{Determination of Calcium and Magnesium by Complexio-metric Titration}

The versenate EDTA titrametric method of Udoh and Ogwuale (1995) were employed. The extract $(20 \mathrm{ml})$ was dispersed into a conical flask and treated with pinches of the masking agent (hydroxylamine and hydrochloride, sodium cyanide and sodium potassium ferro cyanide). The flask was shaken and the mixture dissolved. Ammonia buffer $(20 \mathrm{mls})$ was added to raise the $\mathrm{pH}$ to 10.00 the point at which both calcium and magnesium form complexes with EDTA. The mixture was treated against $0.002 \mathrm{~N}$ EDTA solution using erichrome black $\mathrm{T}$ as an indicator; a reagent blank was also treated as the blank. The colour in each case changed from deep red to a Journal of the Faculty of Agriculture and Veterinary Medicine, Imo State University Owerri website: www ajol.info 
permanent blue end point. Separate titration was done to determine $\mathrm{Ca}^{2+}$ alone in the test sample. Titration of calcium alone was done similarly with the above titration. However, $70 \% \mathrm{NaOH}$ was used in place of ammonia buffer and sole chrome dark blue indicator in place of erichrome black $\mathrm{T}$ from the titre values as shown below:

$$
\mathrm{Ca}(\mathrm{mg} / 100 \mathrm{~g})=\frac{100}{\mathrm{Wt}} \quad \mathrm{x} \quad \mathrm{T}-\mathrm{BN}\left(\underline{\left.\frac{\mathrm{ca} \mathrm{x} \mathrm{V}}{\mathrm{r}}\right)}\right.
$$

Where $\mathrm{Wt}=$ weight of sample, $\mathrm{B}$ litre value of sample, $\mathrm{Ca}=$ Calcium equivalence, $\mathrm{Mg}=$ Magnesium equivalence, $\mathrm{N}=$ Normality of titrate $(0.002 \mathrm{~N}$ EDTA), VT = Total extract volume, $\mathrm{VA}=$ Volume of extract analyzed.

\subsection{Determination of Vitamin Contents}

\section{Vitamin C (Ascorbic acid) Content Determination}

The method described here is the titration method by Onwuka (2005). The unconcentrated sample $(50 \mathrm{ml})$ was pipetted into $100 \mathrm{ml}$ volumetric flask in triplicate. Twenty-five milliliters of $20 \%$ metaphosphoric acid (or $0.5 \%$ oxalic acid) were added as sterilizing agent and diluted into $100 \mathrm{ml}$ volume. Ten milliliters of the sample were pipetted into small flasks in which $2.5 \mathrm{ml}$ acetone were added. This were treated with indophenols solution (2, 6- dichiorophenol indophenol) to form a pink colour precipitate Vitamin $\mathrm{C}$ was calculated as:

Vit. $\mathrm{C}$ content $(\mathrm{mg} / 100 \mathrm{~g})=[\underline{100 \times 0.88} \times \underline{\text { Vtx litre }]}$

W Va

Where $\mathrm{W}=$ weight of sample used, $\mathrm{Vt}=$ Total volume of sample used, Va Volume of sample titrated

\section{Vitamin A Determination}

The method as described by Kirk and Sawyer, (1998) were followed. A measured weight (5.0g) of the sample was dispensed in $30 \mathrm{ml}$ of absolute alcohol. Three milliliter of $5 \% \mathrm{KOH}$ solution were added and boiled under reflux for 30 minutes. After cooling rapidly in running water, $30 \mathrm{mls}$ of distilled water were added to the mixture and transferred into a separation funnel. The lower layer (aqueous) were discarded while the Vitamin A extract was then evaporated to dryness and dissolved in 10ml of isopropyl alcohol and its absorbance of the vitamin A extract was measured at $325 \mathrm{~nm}$. The vitamin A content was calculated using the relationship:

$$
\begin{array}{lll}
\text { Vitamin } A(m g / 100 g)=\underline{100} & \text { x } & \underline{\mathrm{Au}} \times \mathrm{C} \\
\mathrm{W} & \mathrm{As}
\end{array}
$$

Where

$\mathrm{W}=$ weight of sample, As = absorbance of standard vitamin A solution, Au = absorbance of test sample, $\mathrm{C}=$ concentration of standard vitamin $\mathrm{A}(\mathrm{m} / \mathrm{mg})$

\section{Determination of Physiochemical Properties}




\section{pH Value}

The $\mathrm{pH}$ value of the sample was measured with a digital glass-electrode $\mathrm{pH}$ meter at room temperature which was standardized prior to sample $\mathrm{pH}$ measurement using buffer solutions of pH values 4.0 and 7.0 (AOAC, 2012).

\section{Titratable Acidity}

One gramme $(1 \mathrm{~g})$ of the sample was taken, diluted to $20 \mathrm{ml}$ with distilled water, titrated with $0.1 \mathrm{M} \mathrm{NaOH}$, using 0.3 phenolphthalein for each $100 \mathrm{ml}$ of the solution to the pink end point persisting for 30 seconds (AOAC, 2012). Titratable acidity was calculated as

$\mathrm{Ta}=\frac{\mathrm{B} \times 0.1 \times 0.064 \times 100}{\mathrm{w}}$

where $\mathrm{B}=$ Burette reading an $\mathrm{w}=$ weight of the sample.

\section{Total Solids}

Total solid content was determined by subtracting the moisture content from $100 \%$.

$\therefore$ Total solids $(\%)=100$ - \%moisture

\section{Sensory Evaluation}

Sensory evaluation (to determine the organoleptic properties) of the samples was conducted using 30 panel members that were familiar with quality attributes of the sample drinks. Samples were presented on identical containers coded with three digits (letters). A 9-point hedonic scale as described by Ihekoronye and Ngoddy (1985) were used ranging from like extremely (9) to dislike extremely (1). Each sample was rated for appearance, taste, aroma, mouthfeel and overall acceptability.

\section{Statistical Analysis}

Analysis of variance (ANOVA) as described by Iwe (2002) were used to test for significance in the data generated and means separated using the Duncan's multiple Range test. Probabilities less than 0.05 were considered statistical significant $(\mathrm{p}<0.05)$.

\section{RESULTS AND DISCUSSION}

\section{Proximate Compositions of Drink samples from Beetroot and Roselle}

The results of the proximate analysis of the drink samples are presented in Table 2.

Moisture content of the drink samples ranged from 88.13 to $93.03 \%$ with sample A $(100 \%$ beetroot drink) having the highest mean value of 93.03 and sample E (100\% roselle drink) having the lowest mean value of $88.13 \%$. The moisture contents of the mixed samples were between these two extremes. The values for samples A, B and C were significantly different from each other $(p<0.05)$ while those of $D$ and $E$ were not. The values obtained from this study are in agreement with moisture reported for fruit drinks (Babalola et al., 2001), Ojokoh et al., (2003) and Ansaic et al., 2017). The high moisture content found on the samples was an indication that the drink can serve as refreshing thirst-quench drink. 
Protein content values of the samples ranged from 0.09 to $0.31 \%$ with sample A (100\%) having the highest mean value and sample $\mathrm{E}$ the lowest. The values were significantly different (p<0.05). Ansaic, et al; (2017) reported low protein quality of blended beetroot and Jamul juice.

The fat content values of the samples ranged from 0.13 to $0.25 \%$ with sample A having the highest mean value while sample E has the lowest. Samples A, B and C were not significantly different while sample D and E were significantly different. Ash content values of the samples ranged from 0.45 to $0.67 \%$ with sample A having the highest mean value and sample $\mathrm{E}$, the lowest. The samples were significantly different from each other $(p<0.05)$. Ash contents of the samples ranged from 0.45 to $0.67 \%$ with sample A having the highest and sample E the least. The values were significantly different $(\mathrm{p}<0.05)$. Ash in food is a measure of mineral content needed in human nutrition (Onyeka, 2013). The carbohydrate contents ranged from 5.75 to 11.20\%. Samples A, B and C are significantly different while samples D and E are not. It's obvious that the highest proportion of the carbohydrate is made of sugars.

\section{Vitamin and Mineral Contents of the Drink Samples}

Vitamin and mineral contents of mixed drink samples from beetroot and roselle are presented in Table 3. Vitamin A content ranged from 24.64 to $38.04 \mathrm{mg} / 100 \mathrm{~g}$ with sample A having the highest mean value and sample $E$ the lowest. The values were significantly different $(p<0.05)$. Vitamin $A$ as $\beta$-carotene contents of the drinks found in this work was higher than $\beta$-carotene content of hibiscus drink reported by Joseph and Adogbo (2015). Vitamin C contents of the drink samples ranged from 5.67 to $17.08 \mathrm{mg} / 100 \mathrm{~g}$, with sample A having the highest mean value and sample $E$ the lowest. The values were significantly different $(p<0.05)$ from each other. The vitamin $\mathrm{C}$ values obtained in this work are in agreement with findings of Fasoyiro et al; (2005).

Phosphorus contents of the samples shows sample A having the highest mean value of 86.97 while sample $E$ has the lowest mean value of 38.49 . There were significant differences $(p<0.05)$ among the samples.

Iron contents of the samples ranged from 4.79 to $9.69 \mathrm{mg} / 100 \mathrm{~g}$ with sample A having the highest mean value and sample $\mathrm{E}$ the lowest. The values are significantly different from each other ( $\mathrm{p}<0.05$ ). Magnesium contents ranged from 3.01 to $7.71 \mathrm{mg} / 100 \mathrm{~g}$ with sample A having the lowest mean value while sample $\mathrm{E}$ has the highest. The values are significantly different $(\mathrm{p}<0.05)$.

Potassium contents ranged from $4.01 \mathrm{mg} / 100 \mathrm{~g}$ to $7.40 \mathrm{mg} / 100 \mathrm{~g}$ with sample A having the lowest mean value and sample $E$ the highest. The values are significantly different $(p<0.05)$ from each other.

Calcium contents of the samples ranged from 3.50 to $6.29 \mathrm{mg} / 100 \mathrm{~g}$ with sample A having the lowest mean value and sample $\mathrm{E}$ the highest. The values are significantly different from each 
other. Mineral contents of the mixed drink samples were varied which could be due to difference in mineral composition of the single extract from beetroot and Roselle (hibiscus) respectively. This result agreed with the report of Babalola et al., (2001).

\subsection{Physicochemical Properties of the Drink Samples}

Table 4 presents $\mathrm{pH}$, titratable acidity and total solids of drink samples from beetroot and roselle. The $\mathrm{pH}$ values of the samples ranged from 5.62 to 6.00 with sample A having the highest mean value and sample $E$ the lowest. The values were significantly different from each other $(p<0.05)$. The $\mathrm{pH}$ values found in this work are in agreement with $\mathrm{pH}$ of some tropical fruit drinks reported by Emelike et.al., (2016) and Porto et.al., (2017). Titratable acidity of the drink samples ranged from $0.54 \%$ to $0.68 \%$ with sample A having the lowest mean value and sample $\mathrm{E}$ the highest. The values were significantly different from each other. The $\mathrm{pH}$ and titratable acidity results show that the drinks are low-acid foods and the acidity gradually increased with zobo drink increase in the samples. Total solid content of the drink samples ranged from 6.97 to $11.87 \%$ with sample A having the lowest mean value and sample $\mathrm{E}$ the highest. The values for sample $\mathrm{A}$, $\mathrm{B}$, and $\mathrm{C}$ were significantly different while those of $\mathrm{D}$ and $\mathrm{E}$ were not.

\section{Organoleptic Properties of the Drinks}

The results of sensory analysis of the various formulations of beetroot and roselle drinks are presented in Table 5. Appearance of samples ranged from 5.55 to 8.05 with sample A having the lowest mean value and sample E having the highest. Sample C, D and E were not significantly different, sample B was not significantly different from samples C, D and E while sample A was significantly different from other samples in terms of appearance $(p<0.05)$.

Taste of the samples ranged from 3.40 to 8.35 with sample A having the lowest mean value while sample E had the highest. Samples B, C and D were not significantly different.

Aroma rating of the samples ranged from 4.75 to 7.55 with sample A having the lowest mean value and sample E the highest. Samples C, D and E were not significantly different; samples A and $\mathrm{B}$ were not significantly different while sample $\mathrm{C}, \mathrm{D}$ and $\mathrm{E}$ were significantly different from samples A and B.

Mouth feel rating of the samples ranged from 3.15 to 8.65 with sample A having the lowest mean value while sample $\mathrm{E}$ had the highest. The samples were significantly different from each other in terms of mouthfeel. In overall acceptability of the samples, the scores ranged from 3.95 to 8.80 with sample A having the lowest mean score and sample E the highest. All the samples were significantly different from each other.

\section{CONCLUSION}

The study has demonstrated that combining water extracts from beetroot and roselle offers drinks with adequate nutrient compositions and organoleptic characteristics. Though consumers preferred the sample made of only roselle drink (zobo drink) the sample made of $100 \%$ beetroot 
drink proved to be the best in terms of nutrient content. The combination of nutrients from both beetroot and roselle is expected to have a synergistic nutritional advantage. It is here-by recommended that consumers should go for the drinks made of $50 \%$ beetroot and $50 \%$ roselle (Zobo drink) or that made of $25 \%$ beetroot and $75 \%$ roselle. This recommendation will also help those who have some reservations on the taste of pure zobo drink. 


\section{REFERENCES}

Ansaic R., Singh S. B, Kurnar P. and Broadway A. A (2017). Proximate and sensory analysis of beetroot (Beta vulgaris) and Jamun (Syzygium cumini) juice Mended drink. J. Pharmacog and Phytochem; 6(6): 1280-1283.

AOAC (2012) Official methods of Analysis (19 ${ }^{\text {th }}$ Ed.) Association of Analytical Chemists. Washington D.C.

Babalola S. O. Baba1ola A. O. and Aworh, O. C (2001). Compositional Attributes of the Calyces of Roselle (Hibiscus Sabdariffa), J Food Technol. Afri. 6 (4): 133 - 134.

Chen H. H, Tsai P. J. Chens. H, Su Y. M, Chung C. C. and Huang T.C (2005). Grey relational analysis of dried roselle (Hibiscus Saddariffa). J. of Food Science Process. Preserv. 29, 228-245.

Emelike N. J. T., Barber I. I. and Ebere C. O. (2016). Quality Characteristics of Beetroot Juice Treated with Indigenous Spices (Lemon, Ginger and Ehuru) International Journal of Food Science and Nutrition Engineering, 6(1): 1 4- 19.

Joseph, A.D and Adogbo, O .M (2015). Processing and Packaging of Hibiscus Sabdariffa for Preservation of Nutritional Constituents. Scientific and Engineering Research, 6, (4):532

Ihekoronye, A.I. and Ngoddy, P.O. (1985) Integrated food Science and Technology for the Tropics. Macmillan Education Ltd London.

Iwe, M. O. (2002). Handbook of Sensory Methods and Analysis Rejoint Communication Service Ltd., Enugu Nigeria pp75 - 77.

Kanika, K. (2012). Beet Root Juice Benefits. http://www.buzzle.com/article.beetroot (accessed 20th January, 2019).

Lawton, Babara P. (2004). Hibiscus hardy and Tropical Plants for the Garden. Timber press, p.36.

Lee, David Webster (2007), Nature's Palette: The Science of Plant Color. University of Chicago press, p. 183.

Ojokoh, A. O., Adetuyi, F. C., Akinyosoye, F. 0. and Oyetayo, V. 0. (2003). Fermentation studies on roselie Hibiscus sabdariffä) calyx neutralized with Trona. Journal of Food Technology in Africa, 7:75-77.

Onwuka, G.E. (2005). Food Analysis and Instrumentation: Theory and Practice. Naphthali Prints Lagos - Nigeria. 219pp

Onyeka E.U. (2013) Food and Nutrition ( $3^{\text {rd }}$ Ed.) Skillmark Media Ltd, Owerri - Nigeria P. 215. 
Porto, M. R. A., Okina, V. S., Pimentel T. C. and Prudencio, S. H. (2017). Physicochemical Stability, Antioxidant Activity, and Acceptance of Beet and Orange Mixed Juice during Refrigerated Storage. Beverages, 3: 36. 


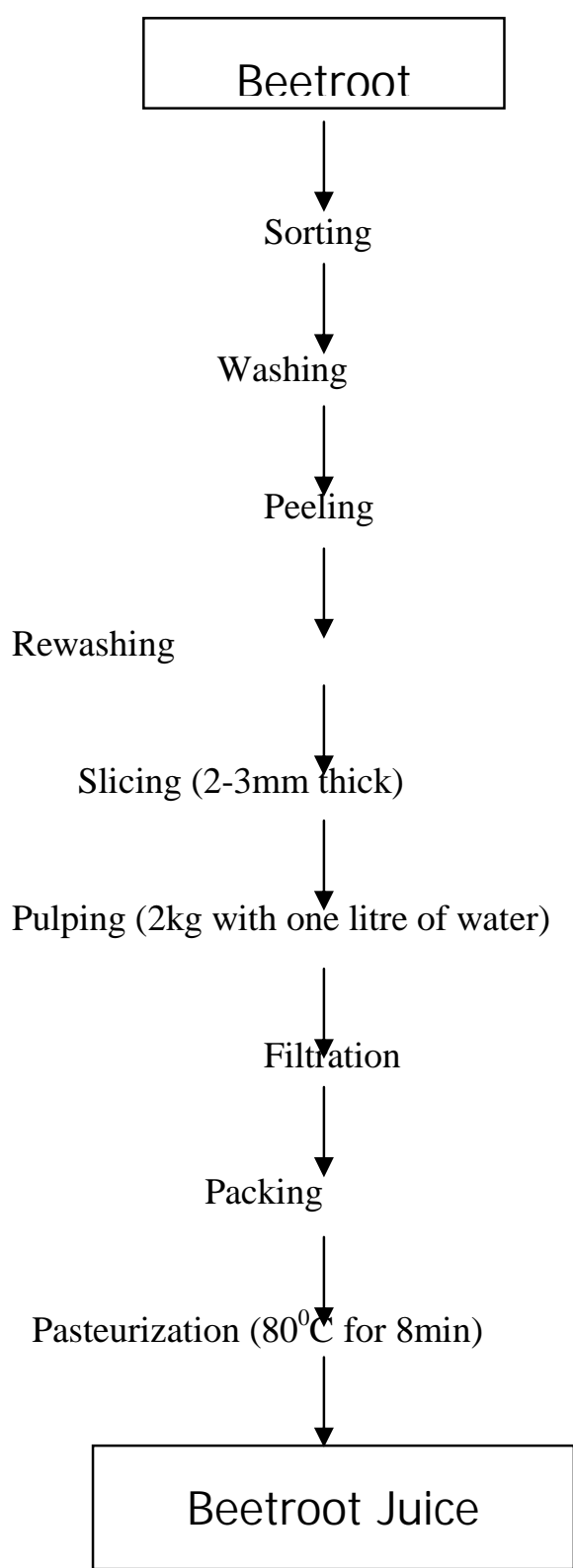

Figure 1: Flow chart for Preparation of Drink from Beetroot 


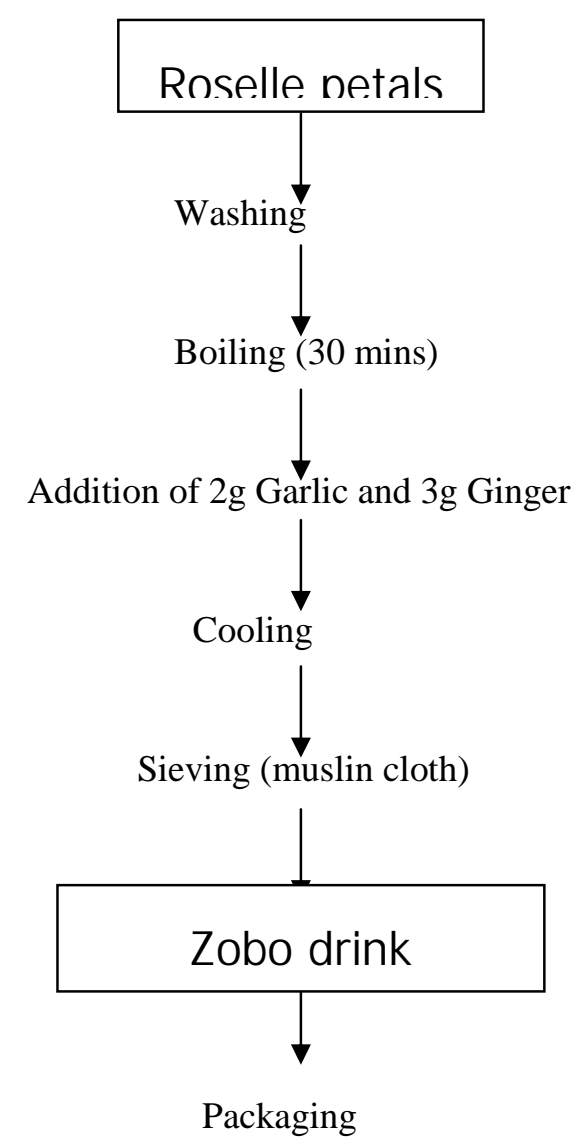

Figure 2: Flow Chart for Production of Zobo Drink 
Journal of Agriculture and Food Sciences

Ebiringa, D.C. and Onyeneke, E. N. 50 Volume 17 Number 1, April 2019 pp

38- 53

Table 1: Mixing of Beetroot Drink and Zobo Drinks in varying Proportions

\begin{tabular}{lllll}
\hline Sample & $\begin{array}{l}\text { Ratio } \\
\text { BD:ZD }\end{array}$ & of & $\begin{array}{l}\text { Volume of beetroot drink } \\
\left(\mathrm{cm}^{3}\right)\end{array}$ & $\begin{array}{l}\text { volume } \\
\left(\mathrm{cm}^{3}\right)\end{array}$ \\
\hline A & $1: 0$ & 500 & 0 & 500 \\
B & $3: 1$ & 375 & 125 & 500 \\
C & $1: 1$ & 250 & 250 & 500 \\
D & $1: 3$ & 125 & 375 & 500 \\
E & $0: 1$ & 0 & 500 & 500 \\
\hline
\end{tabular}

Key: $\mathrm{BD}=$ Beetroot drink

$\mathrm{ZB}=$ Zobo drink

Table 2: Proximate composition of mixed drink from beet root and Hibiscus

\begin{tabular}{llllll}
\hline $\begin{array}{l}\text { Drink } \\
\text { samples }\end{array}$ & Moisture & $\begin{array}{l}\text { Parameter } \\
\text { \% } \\
\text { Protein }\end{array}$ & Fat & Ash & Carbohydrate \\
\hline A & $93.03 \pm 0.02^{\mathrm{a}}$ & $0.31 \pm 0.02^{\mathrm{a}}$ & $0.25 \pm 0.01^{\mathrm{a}}$ & $0.67 \pm 0.01^{\mathrm{a}}$ & $5.75 \pm 0.08^{\mathrm{d}}$ \\
B & $92.40 \pm 0.02^{\mathrm{b}}$ & $0.23 \pm 0.00^{\mathrm{b}}$ & $0.21 \pm 0.00^{\mathrm{b}}$ & $0.63 \pm 0.00^{\mathrm{b}}$ & $6.54 \pm 0.02^{\mathrm{c}}$ \\
C & $89.30 \pm 0.02^{\mathrm{c}}$ & $0.19 \pm 0.00^{\mathrm{c}}$ & $0.18 \pm 0.00^{\mathrm{c}}$ & $0.58 \pm 0.01^{\mathrm{c}}$ & $9.76 \pm 0.03^{\mathrm{b}}$ \\
D & $88.19 \pm 0.02^{\mathrm{d}}$ & $0.16 \pm 0.00^{\mathrm{d}}$ & $0.13 \pm 0.01^{\mathrm{d}}$ & $0.48 \pm 0.01^{\mathrm{d}}$ & $11.04 \pm 0.01^{\mathrm{a}}$ \\
E & $88.13 \pm 0.02^{\mathrm{d}}$ & $0.09 \pm 0.02^{\mathrm{e}}$ & $0.13 \pm 0.00^{\mathrm{d}}$ & $0.45 \pm 0.00^{\mathrm{e}}$ & $11.20 \pm 0.05^{\mathrm{a}}$ \\
& & & & & \\
LSD & 0.024 & 0.0189 & 0.0104 & 0.011 & 0.050 \\
\hline
\end{tabular}

Values $=$ Means \pm SD

Mean values in the same column with different superscripts are significantly different from each other $(\mathrm{p}<0.05)$

Key:

A $=$ Sample made of $100 \%$ Beetroot drink

$\mathrm{B}=$ Sample containing Beetroot and Roselle drinks in the ratio of 3:1

$\mathrm{C}=$ Sample containing Beetroot and Roselle drinks in the ratio of 1:1

$\mathrm{D}=$ Sample containing Beetroot and Roselle drinks in the ratio of 1:3

$\mathrm{E}=$ Sample made of $100 \%$ Roselle drink (zoba drink).

Journal of the Faculty of Agriculture and Veterinary Medicine, Imo State University Owerri website: www ajol.info 
Table 3: Vitamin and mineral contents of drink from beetroot and Roselle

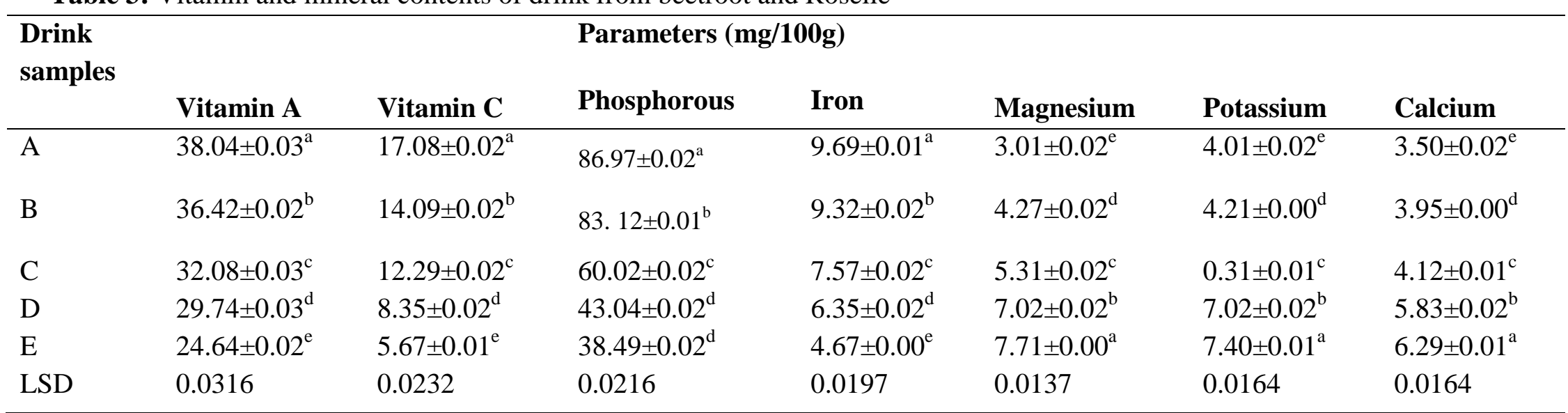

Values $=$ Mean \pm SD

Mean values in the same column with different superscripts are significantly different from each other

Key:

$A=$ Sample made of $100 \%$ Beetroot drink

$\mathrm{B}=$ Sample containing Beetroot and Hibiscus (Roselle) drinks in the ratio of 3:1

$\mathrm{C}=$ Sample containing Beetroot and Hibiscus drinks in the ratio of 1:1

$\mathrm{D}=$ sample containing Beetroot and Hibiscus drinks in the ratio of $1: 3$

$\mathrm{E}=$ Sample made of $100 \%$ Roselle drink (zobo drink) 
Table 4: Physicochemical properties of the drinks from mixed beet root and Hibiscus extracts

\begin{tabular}{|c|c|c|c|c|}
\hline \multirow{2}{*}{$\begin{array}{l}\text { Drink } \\
\text { samples }\end{array}$} & \multicolumn{3}{|c|}{ Physicochemical Properties } & \multirow[b]{2}{*}{ Total solids $(\%)$} \\
\hline & pH & $\begin{array}{l}\text { Titratable } \\
(\mathrm{g} / \mathrm{L})\end{array}$ & Acidity & \\
\hline A & $6.0 \pm 0.00^{\mathrm{a}}$ & $0.54 \pm 0.00^{\mathrm{e}}$ & & $6.97 \pm 0.02^{\mathrm{d}}$ \\
\hline B & $5.93 \pm 0.00^{\mathrm{b}}$ & $0.58 \pm 0.00^{\mathrm{d}}$ & & 7. $60 \pm 0.02^{\mathrm{c}}$ \\
\hline $\mathrm{C}$ & 5. $80 \pm 0.01^{\mathrm{c}}$ & $0.61 \pm 0.00^{\mathrm{c}}$ & & $10.70 \pm 0.02^{b}$ \\
\hline $\mathrm{D}$ & $5.62 \pm 0.01^{\mathrm{e}}$ & $0.66 \pm 0.01^{\mathrm{a}}$ & & $11.80 \pm 0.02^{\mathrm{a}}$ \\
\hline $\mathrm{E}$ & $5.57 \pm 0.01^{\mathrm{d}}$ & $0.68 \pm 0.00^{\mathrm{b}}$ & & $11.87 \pm 0.02^{\mathrm{a}}$ \\
\hline LSD & 0.0118 & 0.00561 & & 0.02429 \\
\hline
\end{tabular}

Mean values in the same column with different superscripts are significantly different from each other $(\mathrm{p}<0.05)$

Key:

$\mathrm{A}=$ Sample made of $100 \%$ Beetroot drink

$\mathrm{B}=$ Sample containing Beetroot and Hibiscus drinks in the ratio of 3:1

$\mathrm{C}=$ Sample containing Beetroot and Hibiscus drinks in the ratio of 1:1

$\mathrm{D}=$ sample containing Beetroot and Hibiscus drinks in the ratio of 1:3

$\mathrm{E}=$ Sample made of $100 \%$ Roselle drink (zobo drink)

Table 5: Organoleptic properties of the drinks from beetroot and roselle

\begin{tabular}{llllll}
\hline $\begin{array}{l}\text { Drink } \\
\text { samples }\end{array}$ & \multicolumn{5}{c}{ Organoleptic Properties } \\
& Appearance & Taste & Aroma & Mouth-feel & $\begin{array}{l}\text { Overall } \\
\text { acceptability }\end{array}$ \\
\hline A & $5.55 \pm 2.11^{\mathrm{c}}$ & $3.40 \pm 2.30^{\mathrm{d}}$ & $4.75 \pm 2.82^{\mathrm{c}}$ & $3.15 \pm 2.03^{\mathrm{c}}$ & $3.95 \pm 1.98^{\mathrm{c}}$ \\
B & $6.55 \pm 1.23^{\mathrm{bc}}$ & $5.15 \pm 1.87^{\mathrm{c}}$ & $5.30 \pm 0.00^{\mathrm{b}}$ & $4.45 \pm 1.76^{\mathrm{d}}$ & $5.60 \pm 1.87^{\mathrm{d}}$ \\
C & $7.15 \pm 1.46^{\mathrm{ab}}$ & $6.60 \pm 1.78^{\mathrm{bc}}$ & $6.05 \pm 1.73^{\mathrm{ab}}$ & $5.90 \pm 1.16^{\mathrm{c}}$ & $6.40 \pm 1.27^{\mathrm{c}}$ \\
D & $8.0 \pm 0.97^{\mathrm{a}}$ & $7.25 \pm 1.83^{\mathrm{ab}}$ & $7.40 \pm 1.46^{\mathrm{a}}$ & $7.85 \pm 0.74^{\mathrm{b}}$ & $7.85 \pm 0.98^{\mathrm{b}}$ \\
E & $8.05 \pm 1.35^{\mathrm{a}}$ & $8.35 \pm 1.03^{\mathrm{a}}$ & $7.55 \pm 1.66^{\mathrm{d}}$ & $8.65 \pm 0.93^{\mathrm{a}}$ & $8.80 \pm 0.69^{\mathrm{a}}$ \\
LSD & 0.467 & 0.573 & 0.633 & 0.447 & 0.459 \\
\hline
\end{tabular}


Mean values in the same column with different superscripts are significantly different from each other $(\mathrm{p}>0.05)$

Key:

$\mathrm{A}=$ Sample made of $100 \%$ Beetroot drink

$\mathrm{B}=$ Sample containing Beetroot and Hibiscus drinks in the ratio of 3:1

$\mathrm{C}=$ Sample containing Beetroot and Hibiscus drinks in the ratio of 1:1

$\mathrm{D}=$ sample containing Beetroot and Hibiscus drinks in the ratio of 1:3

$\mathrm{E}=$ Sample made of $100 \%$ Roselle drink (zobo drink)

It means that the consumers had preference for the samples in the descending order of magnitude as follows:
a) Sample E (100\% zobo drink)
b) Sample D (Beetroot + zobo drink in ratio of 1:3)
c) Sample C (Beetroot + zobo drink in ratio of 1:1)
d) Sample B (Beetroot + zobo drink in ratio of 3:1)
e) Sample A (100\% beetroot drink) 